[Agr. Biol. Chem., Vol. 25, No. 7, p. 550 552, 1961]

\title{
Studies on Allergen of Fasciola hepatica
}

\author{
Part IV. Composition of Allergen $\mathrm{P}_{4}$
}

\author{
By Kazuyuki Maekawa and Masahisa Kushibe \\ Laboratory of Biochemistry, Faculty of Agriculture, Ehime University, Matsuyama, Ehime \\ Received February 20, 1961
}

\begin{abstract}
This paper deals with the composition of an allergenic substance which was isolated from liver fluke by means of phenol extraction and other methods. The preparation is composed of ribonucleic acid (95\%) as its main component and a small amount of peptide $(4.6 \%)$. The ribonucleic acid consists of nearly equal parts of adenylic, guanylic, uridylic and cytidylic acids, and the peptide is made up of aspartic acid, glutamic acid, glycine, cystine, alanine, serine, threonine, valine, leucine, histidine, lysine, and arginine.
\end{abstract}

In the previous paper it was shown that three kinds of allergenic substances were isolated from liver fluke (Fasciola hepatica) ${ }^{1,3}$. One of them was a protein allergen and its composition and character were reported ${ }^{2}$. The others (P 4 and C 5) contained ribonucleic acid as a main component. The fraction $\mathrm{C} 5$ was found in the extract which was separated by phenol treatment, and was electrophoretically homogeneous. The fraction P 4 was separated from the phenol insoluble part, and was electrophoretically and ultracentrifugally homogeneous. The biological ctivities of C 5 and $\mathbf{P} 4$ were so strong that their solutions, which were obtained by dissolving the preparations with 100,000 times Ringer's solution, still showed satisfactory activities at the intradermal reaction for fascioliasis of Cattle ${ }^{3)}$.

The present paper deals with the composition of fraction $\mathbf{P} 4$.

\section{EXPERIMENTAL}

Material. P 4 was obtained from liver fluke according to the.method described previouslys).

1) K. Maekawa, K. Kitazawa and M. Kushibe, Compt. rend. sean. Soc. Biol., 148, 763 (1954)

2) K. Maekawa and M. Kushibe, ibid., 150, 832 (1956),

3) K. Maekawa and M. Kushibe, Agr. Biol. Chem. 25, 542 (1961).

\section{Methods.}

A) On the Nucleic Acid Fraction.

The sample was hydrolysed with $70 \%$ perchloric acid for 1 hour at $100^{\circ} \mathrm{C}$, according to the usual method. The purine and pyrimidine bases were identified, after neutralization of excess acid, by means of paper chromatography in the following solvent: $170 \mathrm{ml}$ of isopropanol, $41 \mathrm{ml}$ of conc. hydrochloric acid, and filled with water to $250 \mathrm{ml}^{4}$. The position of the spots on the chromatogram was detected by ultraviolet light.

On the other hand, $10 \mathrm{mg}$ of the sample was dissolved in $6 \mathrm{ml}$ of water, to which had been added $3 \mathrm{ml}$ of $3 \mathrm{~N}$ sulfuric acid, and then heated for 1 hour at $100^{\circ} \mathrm{C}$. The hydrolysate was diluted to make $10 \mathrm{ml}$ with water. Employing the diluted solution, the amount of purine, ribose, nitrogen and phosphorus was determined as follows. (a) The purine content was determined by Loring's method ${ }^{5}$. (b) To determine ribose, an adaptation of the Mejbaum procedure was used ${ }^{\text {e) }}$. The standard was a freshly made solution of yeast ribonucleic acid (Katayama Co. Ltd.) which was purified three times, hydrolysed under the same condition, and standardized by phosphorus content.

(c) Nitrogen and phosphorus were determined, after digesting with conc. sulfuric acid, by micro Kjeldahl's and Nakamura's methods ${ }^{7}$ respectively.

4) G. R. Wyatt, Biochem. J., 48, 584 (1951).

5) H. S. Loring, J. I. Fairley, H. W. Bortner and H. L. Seagran J. Biol. Chem., 197, 809 (1952).

6) W. E. Trevelyan and J. S. Harrison, Biochem. J., 63, 23 (1956). 
The ratio of mononucleotide was determined by the following method. About $10 \mathrm{mg}$ of the sample was dissolved by adding $1 \mathrm{ml}$ of $1 \mathrm{~N}$ soduim hydroxide, and allowed to stand for 20 hours at $30^{\circ} \mathrm{C}$. The clear hydrolysate was carefully brought to $\mathrm{pH} 5$ with $2 \mathrm{~N}$ hydrochloric acid. In order to identify mononucleotide, the paper ionophoresis was employed as follows: Electrolyte, acetic acid-pyridine buffer $\mathrm{pH} \mathrm{3.98)}$; current, 600 volt, $4 \mathrm{~mA}$; duration, 2 hours.

The determination of each mononucleotide was densitometrically carried out by measuring the extinction of the chromatogram at $260 \mathrm{~m} \mu$, using another chromatogram which was treated in the same way as the procedure described above, dried at $50 \sim 60^{\circ} \mathrm{C}$ for $10 \mathrm{~min}$, and then further dried in a vacuum desiccator over sulfuric acid for 6 hours.

Potassium was determined after being digested with sulfuric acid-nitric acid mixture, by means of flame photometry using $768 \mathrm{~m} \mu$. At the same time, phosphorus was also determined, applying an aliquot portion of the digested solution.

\section{B) On the Peptide.}

The hydrolysate was prepared by heating $10 \mathrm{mg}$ of sample with $1 \mathrm{ml}$ of mixed solution of hydrochloric acid and formic acid ${ }^{9)}$ in a sealed tube for 18 hours at $100^{\circ} \mathrm{C}$, since, in a preliminary experiment, it was confirmed that this condition is satisfactory for the liberation of amino acid without decomposition such as the formation of amino acid from adenine. The resulting solution was concentrated on a boiling water bath, and acids were removed by evaporation to dryness in a vacuum desiccator over sulfuric acid as usual. After dissolving the residue in an aliquot of water, amino acid content was determined by the ninhydrin method ${ }^{10)}$. Each amino acid was identified by two dimensional paper chromatography; first solvent, $n$-buthanol : acetic acid : water :: $4: 1: 2$, second solvent, $80 \%$ phenol.

\section{RESULTS}

The ultraviolet absorption spectrum in aqueous solution is illustrated in Fig. 1. The absorption maximum was 258 261 $\mathrm{m}_{\mu} ; \varepsilon(\mathrm{P})$ was 9150 at max. The reactions with diphenylamine and anthrone were both nega-

\footnotetext{
8) W. Grassman, K. Hanning and M. Plöcke, Z. physiol. Chem., 299, 258 (1955).

9) R. J. Block, Anal. Chem., 22, 1327 (1950).

10) W. Troll and R. K. Cannan, J. Biol. Chem. 200, 803 (1953).
}

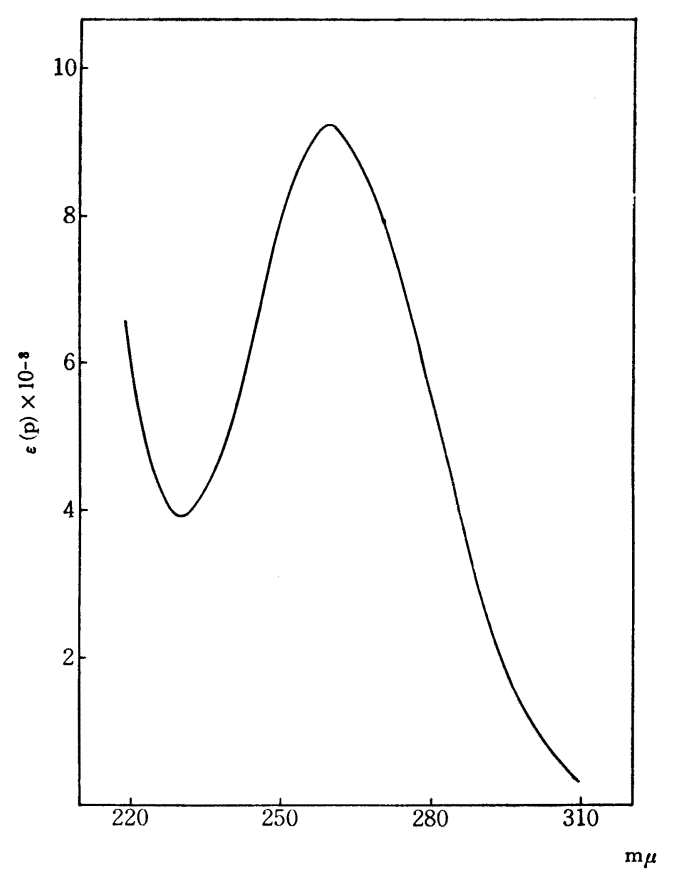

FIG. 1. Absorption Spectrum of P 4 .

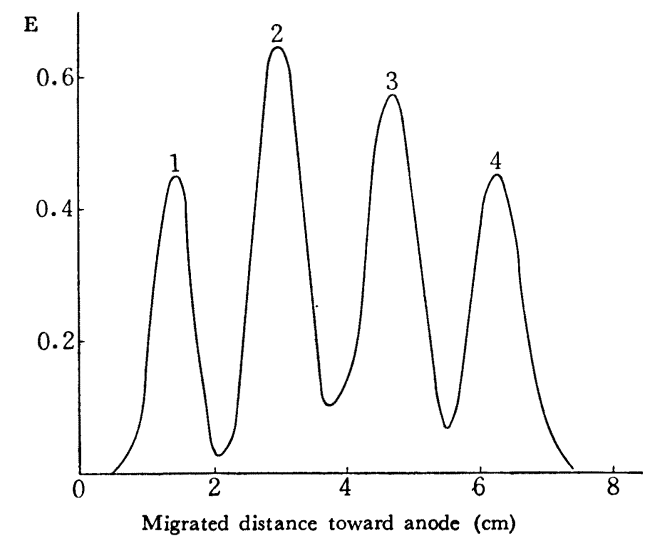

FIG. 2. Densitometric Determination of Mononucleotide Fraction.

Electrolyte ; Acetic acid-pyridine pH 3.98: 600 volts $4 \mathrm{~mA}$; 2 hrs.

$$
\begin{array}{ll}
1 \ldots \text { Cytidylic acid } & 3 \ldots \text { Guanylic acid } \\
2 \ldots \text { Adenylic acid } & 4 \ldots \text { Uridylic acid }
\end{array}
$$

tive. The ninhydrin reaction also was negative.

Nitrogen- and phosphorus content were 8.26 and $14.5 \%(\mathrm{~N} / \mathrm{P}=1.75)$ respectively. In- 
TABle 1. Composition of P 4

\begin{tabular}{lc}
\multicolumn{1}{c}{$\mathrm{P}$} & $8.26 \%$ \\
K & 9.66 \\
Total N-Amino N & 13.7 \\
Amino N & 0.78 \\
Adenine & $63 . \mathrm{Mol} / 10^{5} \mathrm{~g}$. \\
Guanine & 67 \\
Uracil & 65 \\
Cytosine & 70 \\
Ribose & $267 \mathrm{Mol} / 10^{5} \mathrm{~g}$. \\
Asp Glu Gly Cys Ser Thr Ala Lys Arg Val Leu His \\
RNA-K salt & $94.8 \%$ \\
Peptide & 4.6
\end{tabular}

organic phosphate could not be detected and the molar ratio of ribose and phosphorus was $1: 1$. The results are summarized in Table $I$. The result of densitometrical determination of each mononucleotide is shown in Fig. 2.

From this experiment, it has been established that the main component of the sample was potassium salt $(94.8 \%)$ of ribonucleic acid, which consisted of adenylic, guanylic, uridylic and cytidylic acids in molar ratio of $23.5: 25.6: 24.4: 26.5$.

The preparation, $\mathrm{P} 4$, behaves as a single component on physical criteria, but always contains a small amount of peptide $(0.207$ mol $\mathrm{NH}_{2}$ /gram-atom of $\mathrm{P}$ ). Furthermore, in spite of repeated purification, the amino nitrogen could not be removed. It may be therefore supposed that the peptide combines with nucleic acid.

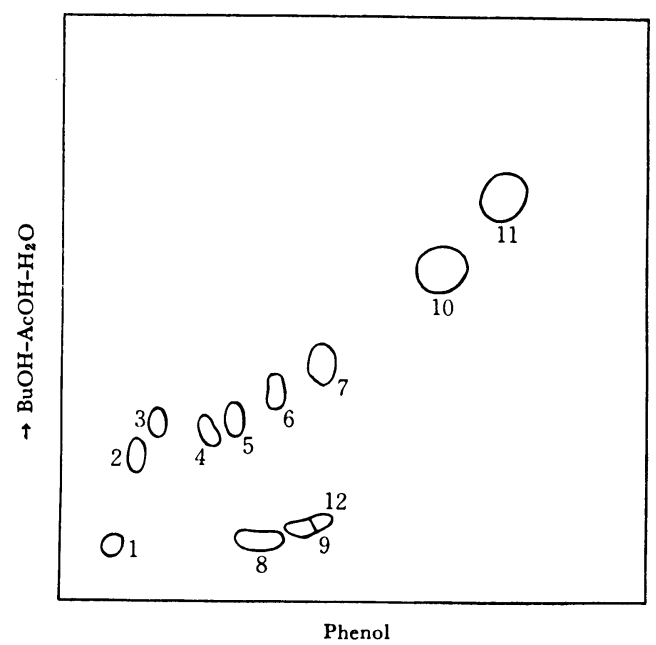

FIG. 3. Paper Chromatogram of Hydrolysate of $\mathbf{P} 4$.

1. Csy, 2. Asp, 3. Glu, 4. Ser, 5. Gly, 6. Thr, 7. Ala, 8. Lys, 9. Arg, 10. Val, 11, Leu. 12, His.

The acid hydrolysis of the preparation indicated that the peptide is made up of aspartic acid, glutamic acid, glycine, cystine, alanine, serine, threonine, valine, leucine, histidine, lysine and arginine, as illustrated in Fig. 3.

\section{SUMMARY}

The allergenic substance, $P 4$, which was separated from liver fluke (Fasciola hepatica) is a complex of ribonucleic acid and a small quantity of peptide. This ribonucleic acid consists of nearly equal parts of adenylic, guanylic, uridylic and cytidylic acids. 